\title{
Article/Artigo
}

\section{Nosocomial infections in a Brazilian neonatal intensive care unit: a 4-year surveillance study}

\author{
Infecções hospitalares em uma unidade de terapia intensiva neonatal brasileira: vigilância de \\ quatro anos
}
Denise Von Dollinger Brito ${ }^{1}$, Cristiane Silveira de Brito ${ }^{1}$, Daiane Silva Resende ${ }^{1}$, Jacqueline Moreira do Ó$^{1}$, Vânia Olivetti Steffen Abdallah ${ }^{2}$ and Paulo Pinto Gontijo Filho ${ }^{1}$

\begin{abstract}
Introduction: Report the incidence of nosocomial infections, causative microorganisms, risk factors associated with and antimicrobial susceptibility pattern in the NICU of the Uberlândia University Hospital. Methods: Data were collected through the National Healthcare Safety Network surveillance from January 2006 to December 2009. The patients were followed five times/week from their birth to their discharge or death. Results: The study included 1,443 patients, 209 of these developed NIs, totaling 293 NI episodes, principally bloodstream infections $(203 ; 69.3 \%)$ and conjunctivitis $(52 ; 17.7 \%)$. Device-associated infection rates were as follows: 17.3 primary bloodstream infections per 1,000 central line-days and 3.2 pneumonias per 1000 ventilator-days. The mortality rate in neonates with NI was $11.9 \%$. Mechanical ventilation, total parenteral nutrition, orogastric tube, previous antibiotic therapy, use of CVC and birth weight of 751-1,000g appeared to be associated with a significantly higher risk of $\mathrm{NI}(\mathrm{p} \leq 0.05)$. In multiple logistic regression analysis for NI, mechanical ventilation and the use of CVC were independent risk factors $(\mathrm{p} \leq 0.05)$. Coagulase- negative Staphylococcus (CoNS) (36.5\%) and Staphylococcus aureus (23.6\%) were the most common etiologic agents isolated from cultures. The incidences of oxacillin-resistant CoNS and S. aureus were $81.8 \%$ and $25.3 \%$, respectively. Conclusions: Frequent surveillance was very important to evaluate the association of these well-known risk factors with NIs and causative organisms, assisting in drawing the attention of health care professionals to this potent cause of morbidity.

Key-words: Neonates. Surveillance system. Nosocomial infection.
\end{abstract}

\section{RESUMO}

Introdução: Relatar a incidência das infecções hospitalares, microrganismos causadores, fatores de risco associados e o padrão de susceptibilidade aos antimicrobianos na UTI neonatal do Hospital Universitário de Uberlândia. Métodos: Realizou-se vigilância National Healthcare Safety Network de janeiro de 2006 a dezembro de 2009. Os pacientes foram acompanhados cinco vezes por semana desde o seu nascimento até a alta ou óbito. Resultados: O estudo incluiu 1.443 pacientes dos quais 209 desenvolveram infecção hospitalar, totalizando 293 episódios de IHs, com destaque para as infecções de corrente sanguínea $(203 ; 69,3 \%)$ e conjuntivite (52; 17,7\%). As taxas de infecção associadas a dispositivos foram as seguintes: 17,3 infecções da corrente sanguínea primária por $1.000 \mathrm{CVC}$ dia e 3,2 pneumonias por 1.000 ventiladoresdia. A taxa de mortalidade em recém-nascidos com infecções hospitalares foi de 11,9\%. A ventilação mecânica, nutrição parenteral total, sonda orogástrica, antibioticoterapia prévia, uso de CVC e peso de 751-1.000g pareceu estar associado com um risco significativamente maior de $\mathrm{IH}(\mathrm{p} \leq 0,05)$. Na análise de regressão logística múltipla para IH, ventilação mecânica e uso de CVC foram fatores de risco independentes $(\mathrm{p} \leq 0,05)$. Staphylococcus coagulasenegativo (SCoN) (36,5\%) e Staphylococcus aureus (23,6\%) foram os agentes etiológicos mais comumente isolados. A incidência de $\mathrm{SCoN} \mathrm{e} \mathrm{S}$. aureus resistente à oxacilina foram de $81,8 \%$ e 25,3\%, respectivamente. Conclusões: Uma vigilância frequente foi importante para avaliar a associação de fatores de risco bem conhecidos com as IHs e etiologia com a finalidade de chamar a atenção dos profissionais de saúde para esta grande causa de morbidade.

Palavras-chaves: Neonatos. Sistema de vigilância. Infecção hospitalar.

1. Microbiology Laboratory, Biomedical Science Institute, Federal University of Uberlândia, Uberlândia, MG, Brazil. 2. Neonatology Department, Uberlândia University Hospital, Federal University of Uberlândia, Uberlândia, MG, Brazil.

Address to: Dra Cristiane Silveira de Brito. Lab. Microbiologia/ICBIM/UFU. Av. Amazonas, Bloco 4C $\mathrm{s} / \mathrm{n}, 2^{\circ}$ andar, Campus Umuarama, 38400-902 Uberlândia, MG, Brazil.

Phone: 5534 3218-2236.

e-mail: cristianebrito08@yahoo.com.br

Received in 26/05/2010

Accepted in 20/08/2010

\section{INTRODUCTION}

Nosocomial infections (NIs) are one of the leading causes of mortality and morbidity in neonatal intensive care units (NICUs). The incidence of infections varies widely among NICUs (7-25.5\%), depending on environmental factors and differences in clinical practice ${ }^{1}$.

Critically ill premature infants are especially vulnerable to nosocomial infections, because of the severity of theirillness and exposure to invasive medical devices. Despite the recent advances in intensive medical care, while lifesaving, they expose critically ill patients to several infectious complications ${ }^{2,3}$.

Bloodstream infections (BSI) are the most frequent neonatal infection in the NICU (45-55\%), followed by respiratory infections (16-30\%) and urinary tract infections $(8-18 \%)^{1}$. Low gestational age and birth weight are the two most frequently identified individual risks for $\mathrm{NI}^{4}$.

Birth weight has been advocated by the Centers for Disease Control and Prevention (CDC) as a variable for device-associated NI risk-stratified rate reporting in high-risk nurseries; however, this strategy has been rarely evaluated in neonates who are admitted to neonatal NICU in developing countries ${ }^{3}$.

Most late-onset infections in neonates who have a BSI in NICUs of industrialized countries are caused by Gram-positive organisms (55.4-75\%); coagulase-negative staphylococci (CoNS) alone are the most commonly isolated pathogens. In contrast, the predominant organisms isolated from invasive neonatal infections in developing countries are Gram-negative organisms, which account for $18-31.2 \%$ of infections ${ }^{5}$.

Surveillance of NIs is an essential part of quality patient care; however, there are few reports of National Healthcare Safety Network (NHSN) surveillance use in NICUs and none in developing countries ${ }^{2}$.

The objectives of this study were to report the incidence of NIs, causative organisms, risk factors associated with and antimicrobial susceptibility patterns through NHSN surveillance with at least four years participation in Neonatal Intensive Care Unit (NICU). 


\section{METHODS}

The Medical Hospital of the Federal University of Uberlândia is a 503-bed public, teaching, general hospital and a tertiary care center. The NICU consists of 1 room with a capacity of 10 neonates and also serves as a referral center for several hospitals in the vicinity.

The working situation is characterized by adequate available space in a new building, with an average of 6 nurses, backed up a neonatologist for 24 hour periods, who provide care for the neonates at all times. One chief neonatologist is responsible for the unit as a whole and works on a daily basis. Consultant support is available from nutrition services, radiology and pediatric surgery. A physical therapist is also present in the unit for 12-hour periods. When entering the NICU, staff and visitors are requested to follow standard handwashing procedures.

Data were collected through the NHSN surveillance system from January 2006 to December 2009. All neonates admitted for more than 24 hours were included, but participation in the study was voluntary and confidential. The patients included in the research were followed five times per week from their birth to their discharge or death and followed-up through epidemiological surveillance, according to the National Healthcare Safety Network (NHSN). The neonates were stratified into the following categories: $\leq 750 \mathrm{~g}, 751-1,000 \mathrm{~g}$, $1,001-1,500 \mathrm{~g}, 1,501-2,500 \mathrm{~g}$, and $>2,500 \mathrm{~g}$.

The following information was recorded on a specific form: birth weight, exposure to vascular catheters, previous antibiotic therapy (use prior to five days of infection), total parenteral nutrition, mechanical ventilation, orogastric tube and gestational age.

Cases of NIs were determined using modified CDC definitions ${ }^{6}$. Patient-days and device-days were collected for central venous catheters (CVC) and mechanical ventilation. The descriptive statistics were provided for each year of participation and the data summated. The incidence of NIs (number of patients with at least one NI per 100 patients) and device-associated NI rates (number of device-associated NIs per 1,000 device-days) were calculated for each unit and totaled for each year of participation. Additionally, incidence densities of clinically diagnosed and microbiologically confirmed NIs were calculated.

Specimens for culture were collected based on clinical criteria established by the medical staff. Microbiological data were obtained from the Microbiology Laboratory of the Uberlândia University Hospital.

Differences between groups with and without NI were assessed for statistical significance using the $\chi^{2}$ distribution test. The following risk factors were assessed: birth weight, gestational age, mechanical ventilation, total parenteral nutrition (TPN), orogastric tube, central venous catheter and antibiotic therapy. A multiple logistic regression model with stepwise forward variable selection was performed to identify significant independent risk factors for NI. The significance level for entering a variable in the model was $\mathrm{p} \leq 0.05$. Data were analyzed using SAS version 9.1, SPSS 12.0 and Epi-Info 6.04.

\section{Ethical}

Ethical approval was obtained from the Ethics Committee of Uberlândia Federal University according to the requirements of the Ministry of Health.

\section{RESULTS}

The study included 1,443 patients, which represented 14,452 patient-days. In total, 209 infants developed nosocomial infection, of these 84 (40.2\%) had more than one infection, totaling NIs 293, principally 203 (69.3\%) BSIs and $52(17.7 \%)$ conjunctivitis.

The average weight was $1,867.9 \mathrm{~g}$, prevailing those which weigh between $1,501 \mathrm{~g}$ and $2,500 \mathrm{~g}(29.9 \%)$. The gestational age above 31 weeks was $69.9 \%$. The average length of stay in the unit was 13.5 days.

The density of the use of invasive devices was 0.7 for CVC and 0.3 for mechanical ventilation. The device-associated infection rates were as follows: 17.3 primary bloodstream infections per 1,000 central line-days and 3.2 pneumonias per 1,000 ventilators-days. The mortality rate in neonates with NI was $11.9 \%$. Overall mortality was $8.5 \%$ (Table 1 ).
TABLE 1 - Characteristics of patients, device use and number of nosocomial infections.

\begin{tabular}{|c|c|c|c|c|c|}
\hline & \multirow[b]{2}{*}{ Total } & \multicolumn{4}{|c|}{ Year of participation } \\
\hline & & $1^{\text {st }}$ & $2^{\text {nd }}$ & $3^{\text {rd }}$ & $4^{\mathrm{rd}}$ \\
\hline \multicolumn{6}{|l|}{ General } \\
\hline neonates (n) & 1,443 & 393 & 337 & 283 & 430 \\
\hline pooled mean birthweight $(\mathrm{g})$ & $1,867.9$ & $1,891.7$ & $1,488.0$ & $2,174.5$ & $1,917.4$ \\
\hline \multicolumn{6}{|l|}{ Proportion (\%) of neonates } \\
\hline \multicolumn{6}{|l|}{ of birthweight classes } \\
\hline$\leq 750 \mathrm{~g}$ & 5.8 & 5.6 & 4.2 & 4.2 & 8.4 \\
\hline $751-1,000 \mathrm{~g}$ & 10.4 & 13.6 & 9.1 & 7.8 & 10.2 \\
\hline $1,001-1,500 \mathrm{~g}$ & 24.7 & 27.5 & 25.2 & 22.6 & 23.3 \\
\hline $1,501-2,500 \mathrm{~g}$ & 29.9 & 28.1 & 31.3 & 34.3 & 27.9 \\
\hline$>2,500 \mathrm{~g}$ & 29.2 & 25.2 & 30.2 & 31.1 & 30.2 \\
\hline Patient-days (n) & 14,452 & 3,525 & 3,334 & 3,692 & 3,901 \\
\hline
\end{tabular}

\section{Proportion (\%) of}

\section{neonates by gestational weeks}

$\begin{array}{lrrrrr}\text { up to week 26 } & 4.2 & 6.6 & 3.9 & 3.5 & 2.8 \\ \text { week 27-28 } & 10.9 & 14.2 & 9.4 & 11.7 & 8.6 \\ \text { week 29-30 } & 15.0 & 13.6 & 14.5 & 18.4 & 14.4 \\ \text { week 31 and beyond } & 69.9 & 65.6 & 72.2 & 66.4 & 74.2 \\ \text { neonates died (\%) } & 8.5 & 9.2 & 9.5 & 8.1 & 7.2\end{array}$

\section{Devices-utilization rates}

[(n of device-days/n of patient-days) $\mathbf{x} 100]$

$\begin{array}{llllll}\text { central venous catheter } & 0.7 & 0.7 & 0.7 & 0.7 & 0.7\end{array}$

$\begin{array}{llllll}\text { mechanical ventilation } & 0.3 & 0.2 & 0.2 & 0.3 & 0.3\end{array}$

\begin{tabular}{lrrrrr}
\hline Neonates (n) with NIs (\%) & & & & & \\
bloodstream infection & 183 & 27 & 37 & 54 & 65 \\
conjunctivitis & 54 & 4 & 11 & 21 & 18
\end{tabular}

\section{Pneumonia}

nosocomial infections

$\begin{array}{lllllll}\left(\mathrm{n}^{\circ} \text { of NIs } / \mathrm{n}^{\circ} \text { of device days x } 1,000\right) & 14 & 2 & 1 & 4 & 7\end{array}$

bloodstream infection (CVC-associated) $17.3 \quad 11.8 \quad 18.2 \quad 20.6 \quad 17.8$

pneumonia (VAP-associated)

$\begin{array}{lllll}3.2 & 2.3 & 1.3 & 4.1 & 6.1\end{array}$

$\mathrm{n}$ : number, NIs: nosocomial infections, CVC: central venous catheter, VAP: ventilatorassociated pneumonia. 
Risk factors for infection are shown in Table 2. Mechanical ventilation, total parenteral nutrition, orogastric tube, previous antibiotic therapy, use of CVC and birth weight of 751-1,000g appeared to be associated with a significantly higher risk of NI $(\mathrm{p} \leq 0.05)$. In multiple logistic regression analysis for NI, mechanical ventilation, use of $\mathrm{CVC}$ and use of orogastric tube were independent risk factors $(\mathrm{p} \leq 0.05)$.
A total of 301 pathogens were isolated from cultures of patients with clinical evidence of infection: blood (203 samples), ocular secretion (52 samples) and urine (12 samples) were the most frequent (Table 3). Coagulase-negative Staphylococcus (36.5\%) and Staphylococcus aureus (23.6\%) were the most common etiologic agents isolated from cultures. The Gram-negative aerobic bacilli accounted for $20.9 \%$ of all episodes. Eight nosocomial infections were polymicrobial.

TABLE 2 - Neonates with and without infection and exposure to risk factors.

\begin{tabular}{|c|c|c|c|c|c|c|}
\hline \multirow[b]{2}{*}{ Risk factors } & \multicolumn{2}{|c|}{$\begin{array}{l}\text { With infection } \\
\qquad(\mathrm{n}=225)\end{array}$} & \multicolumn{2}{|c|}{$\begin{array}{l}\text { Without infection } \\
\qquad(\mathrm{n}=506)\end{array}$} & \multirow[b]{2}{*}{$\mathrm{P}^{*}$} & \multirow[b]{2}{*}{$\mathrm{OR}(\mathrm{CI})$} \\
\hline & $\mathrm{n}$ & $\%$ & $\mathrm{n}$ & $\%$ & & \\
\hline Mechanical ventilation & 139 & 61.8 & 181 & 35.8 & $<0.001^{*}$ & $2.90(2.07-4.07)$ \\
\hline TPN & 153 & 68.0 & 193 & 38.1 & $<0.001^{*}$ & $3.45(3.44-4.87)$ \\
\hline Orogastric tube & 207 & 92.0 & 425 & 84.0 & $0.005^{*}$ & $2.19(1.25-3.89)$ \\
\hline Central venous catheter & 197 & 87.6 & 316 & 62.5 & $<0.001^{*}$ & $4.23(2.69-6.70)$ \\
\hline Previous use of antibiotics** & 155 & 68.9 & 171 & 33.8 & $<0.001^{*}$ & $4.34(3.06-6.17)$ \\
\hline \multicolumn{7}{|l|}{ Birthweight classes } \\
\hline$\leq 750 \mathrm{~g}$ & 15 & 6.7 & 22 & 4.3 & 0.250 & $1.57(0.76-3.23)$ \\
\hline $751-1,000 \mathrm{~g}$ & 30 & 13.3 & 27 & 5.3 & $0.003^{*}$ & $2.73(1.53-4.88)$ \\
\hline $1,001-1,500 \mathrm{~g}$ & 56 & 24.9 & 102 & 20.3 & 0.180 & $1.31(0.89-1.94)$ \\
\hline $1,501-2,500 \mathrm{~g}$ & 58 & 25.8 & 194 & 38.3 & 0.001 & $0.56(0.39-0.80)$ \\
\hline$>2,500 \mathrm{~g}$ & 66 & 29.3 & 161 & 31.8 & 0.550 & $0.89(0.62-1.27)$ \\
\hline \multicolumn{7}{|l|}{ Gestational weeks } \\
\hline up to week 26 & 7 & 3.1 & 27 & 5.3 & 0.250 & $0.57(0.22-1.40)$ \\
\hline week $27-28$ & 31 & 13.8 & 46 & 9.1 & 0.070 & $1.6090 .96-2.67)$ \\
\hline week 29-30 & 33 & 14.7 & 57 & 11.3 & 0.240 & $1.35(0.83-2.20)$ \\
\hline week 31 and beyond & 154 & 68.4 & 376 & 74.3 & 0.120 & $0.75(0.52-1.07)$ \\
\hline
\end{tabular}

OR: odds ratio, $\mathrm{CI}$ : confidence interval, $\mathrm{n}$ : number, TPN: total parenteral nutrition.

${ }^{*} \mathrm{p} \leq 0.05$ considered significant, ${ }^{* *}$ Previous use of antibiotics: use prior to 5 days of infection

TABLE 3 - Distribution of nosocomial infections.

\begin{tabular}{|c|c|c|c|c|c|c|c|c|}
\hline \multirow[b]{3}{*}{ Microorganisms } & \multicolumn{8}{|c|}{ Site of infection } \\
\hline & \multicolumn{2}{|c|}{ BSI } & \multicolumn{2}{|c|}{ conjunctivitis } & \multicolumn{2}{|c|}{ urinary tract } & \multicolumn{2}{|c|}{ others* } \\
\hline & $\mathrm{n}$ & $\%$ & $\mathrm{n}$ & $\%$ & $\mathrm{n}$ & $\%$ & $\mathrm{n}$ & $\%$ \\
\hline \multicolumn{9}{|l|}{ Gram-positive } \\
\hline CoNS & 88 & 43.4 & 14 & 26.9 & 0 & 0.0 & 8 & 23.5 \\
\hline Staphylococcus aureus & 48 & 23.7 & 14 & 26.9 & 1 & 8.3 & 8 & 23.5 \\
\hline Streptococcus & 8 & 3.9 & 3 & 5.8 & 0 & 0.0 & 0 & 0.0 \\
\hline Enterococcus & 9 & 4.4 & 1 & 1.9 & 3 & 25.0 & 2 & 5.9 \\
\hline \multicolumn{9}{|l|}{ Gram-negative } \\
\hline Serratia marcescens & 4 & 2.0 & 1 & 1.9 & 0 & 0.0 & 1 & 2.9 \\
\hline Enterobacter sp & 9 & 4.4 & 5 & 9.6 & 1 & 8.3 & 2 & 5.9 \\
\hline Escherichia coli & 7 & 3.4 & 1 & 1.9 & 1 & 8.3 & 1 & 2.9 \\
\hline Klebsiella pneumoniae & 1 & 0.5 & 3 & 5.8 & 0 & 0.0 & 5 & 14.8 \\
\hline Citrobacter sp & 2 & 1.0 & 0 & 0.0 & 0 & 0.0 & 4 & 11.8 \\
\hline Acinetobacter sp & 5 & 2.5 & 0 & 0.0 & 1 & 8.3 & 0 & 0.0 \\
\hline Pseudomonas aeruginosa & 3 & 1.5 & 10 & 19.3 & 0 & 0.0 & 2 & 5.9 \\
\hline \multicolumn{9}{|l|}{ Fungi } \\
\hline Candida albicans & 9 & 4.4 & 0 & 0.0 & 5 & 41.8 & 1 & 2.9 \\
\hline Others $^{* *}$ & 10 & 4.9 & 0 & 0.0 & 0 & 0.0 & 0 & 0.0 \\
\hline Total & 203 & 100.0 & 52 & 100.0 & 12 & 100.0 & 34 & 100.0 \\
\hline
\end{tabular}


TABLE 4 - Selected antimicrobial susceptibility patterns of blood culture isolates.

\begin{tabular}{lrrr}
\hline & Isolates tested & \multicolumn{2}{c}{ Resistance } \\
\cline { 2 - 4 } Microorganism/antimicrobial & $\mathrm{n}$ & $\mathrm{n}$ & $\%$ \\
\hline CoNS/oxacillin & 110 & 90 & 81.8 \\
Staphylococcus aureus/oxacillin & 71 & 18 & 25.3 \\
Staphylococcus aureus/vancomycin & 71 & 1 & 1.4 \\
Enterococcus/vancomycin & 15 & 0 & 0.0 \\
Serratia marcescens/third-generation cephalosporins* & 6 & 3 & 50.0 \\
Enterobacter/third-generation cephalosporins & 17 & 11 & 64.7 \\
Escherichia coli/third-generation cephalosporins & 10 & 2 & 20.0 \\
Klebsiella pneumoniae/third-generation cephalosporins* & 9 & 4 & 44.4 \\
Acinetobacter/third-generation cephalosporins & 6 & 4 & 66.7 \\
Pseudomonas aeruginosa/carbapenems** & & 0 & 0.0 \\
Pseudomonas aeruginosa/quinolones** & 15 & 0 & 0.0 \\
Pseudomonas aeruginosa/ceftazidime & 15 & 0 & 0.0 \\
\hline N: number, CoNS: coagulase-negative staphylococci. & & & \\
${ }^{*}$ ceftriaxone, cefotaxime or ceftazidime, ${ }^{* *}$ imipenem or meropenem, ${ }^{* * *}$ ciprofloxacin or ofloxacin.
\end{tabular}

Selected antimicrobial susceptibility patterns are presented in Table 4. The incidences of oxacillin-resistant CoNS and S. aureus were $81.8 \%$ and $25.3 \%$, respectively. Of special interest is the high resistance of Acinetobacter sp, Enterobacter sp, Serratia marcescens and Klebsiella pneumoniae to third-generation cephalosporin.

\section{DISCUSSION}

Analysis of the data obtained suggests that participation in surveillance systems, like the NHSN, is important for feeding back individual NICU data for comparison with other literature data. However, comparing surveillance data from different countries is not straightforward. For example, rates of device use vary widely between different countries, suggesting either differences in illness severity or in clinical practice ${ }^{7}$.

Very limited information is available from developing countries regarding infection rates per hospital-days or device-days; standard hospital epidemiological measures adjusted for the duration of exposure to the hospital environment or to invasive devices, such as intravascular catheters or mechanical ventilation. As in most previous reports, BSI was the main cause of $\mathrm{NI}^{3,8,9}$. In this study, BSI occurred at a rate of 10.0 per 1,000 patient-days and accounted for $69.3 \%$ of all infections. A higher proportion (17.3 per 1,000 CVC days) of all BSIs could be linked etiologically to a CVC. With respect to VAP (ventilator-associated pneumonia), the rate obtained was 3.2 per 1,000 ventilator-days. According to the NHSN, median VAP rates were 2.0 per 1,000 ventilator-days ${ }^{10}$. Since many NHSN hospitals use only microbiology reports to identify patients with VAP, NHSN rates may under-estimate the true incidence of VAP. Therefore, the current VAP rate was probably more representative, with all diagnoses of VAP confirmed based on the review of patient medical records and microorganisms recovered from tracheal aspirates on the day of diagnosis.

The $11.9 \%$ mortality in infected patients compared with an overall mortality of $8.5 \%$ during the study period, indicates that infected patients may have a higher likelihood of dying than noninfected patients.

In the present patient population, a statistically significant different occurred between the groups with and without infection with respect to mechanical ventilation, total parenteral nutrition, orogastric tube, previous antibiotic therapy, use of CVC and birth weight of $751-1,000 \mathrm{~g}$. These results are in strong agreement with other studies ${ }^{11,12}$.

Gram-negative rods are major pathogens of neonatal sepsis in developing countries ${ }^{13}$. In NICUs, following the adoption of sophisticated tertiary neonatal care with a high rate of invasive device use, coagulase-negative staphylococci (CoNS) stand out as the main agents of neonatal nosocomial sepsis ${ }^{14}$, with Staphylococcus epidermidis the most frequently isolated from late onset sepsis ${ }^{15}$. Neonatal infection by CoNS is less severe, but causes significant morbidity, especially among infants of very low birth weight ${ }^{11}$. In this study, coagulase-negative Staphylococcus (CoNS) was the most common microorganism causing NIs with microbiological diagnoses.

Most CoNS isolates recovered from infants in this study were resistant to oxacillin. Nevertheless, similar to findings reported by Celebi et $\mathrm{al}^{16}$, clinical improvement was documented in more than half of the infants. The CoNS isolate represented true bacteremia and all study patients met the clinical criteria for sepsis. One possible explanation is that CoNS is a low virulence pathogen. According to Ben Jaballah ${ }^{17}$, high resistance to third generation cephalosporin by Gram-negative bacilli has increased, including Acinetobacter sp, Enterobacter sp, Serratia marcescens and Klebsiella pneumonia; however, it should be noted that only a small number of GNB samples were isolated in this study.

The most important NI remains BSI with staphylococci, enterobacteria and Candida as predominant pathogens, which showed much higher rates than those reported in the literature. Multiresistant microorganisms, especially oxacillin-resistant staphylococci and Gram-negative bacilli resistant to cephalosporin were frequent. Risk factors were the same as in others studies; however, the use of CVC, mechanical ventilation and orogastric tube were independently associated with NIs. The process of evaluating the association of these well-known risk factors with nosocomial infections and causative organisms was valuable and assisted in drawing the attention of health care professionals to this important cause of morbidity. 
CONFLICT OF INTEREST

The authors declare that there is no conflict of interest.

\section{REFERENCES}

1. Borguesi A, Stronati M. Strategies for the prevention of hospital acquired infections in the neonatal intensive care unit. J Hosp Infect 2008; 68:293-300.

2. Schwab F, Geffers C, Bärwolff S, Rüden H, Gastmeier P. Reducing neonatal bloodstream infections through participation in a national surveillance system. J Hosp Infect 2007; 65:319-325.

3. Couto RC, Carvalho EA, Pedrosa TM, Pedroso ER, Neto MC, Biscione FM. A 10-year prospective surveillance of nosocomial infections in neonatal intensive care units. Am J Infect Control 2007; 35:183-189.

4. Olsen AL, Reinholdt J, Jensen AM, Andersen LP, Jensen ET. Nosocomial infection in a Danish neonatal intensive care unit: a prospective study. Acta Paediatr 2009; 98:1294-1298.

5. Srivastava S, Shetty N. Healthcare-associated infections in neonatal units: lessons from contrasting worlds. J Hosp Infect 2007; 65: 292-306.

6. Gastmeier P, Geffers C, Schwab F, Fitzner J, Obladen M, Rüden H. Development of a surveillance system for nosocomial infections: the component for neonatal intensive care units in Germany as an example. J Hosp Infect 2004; 57:126-131

7. Geffers C, Baerwolff S, Schwab F, Gastmeier P. Incidence of healthcare-associated infections in high-risk neonates: results from the German surveillance system for very-low-birthweight infants. J Hosp Infect 2008; 68:214-221.

8. Curtis C, Shetty N. Recent trends and prevention of infection in the neonatal intensive care unit. Curr Opin Infect Dis 2008; 21:350-356.

9. Garland JS, Alex CP, Sevallius JM, Murphy DM, Good MJ, Volberding AM, et al. Cohort study of the pathogenesis and molecular epidemiology of catheter-related bloodstream infection in neonates with peripherally inserted central venous catheters. Infect Contr Hosp Epidemiol 2008; 29:243-249.

10. Edwards JR, Peterson KD, Andrus ML, Tolson JS, Goulding JS, Dudeck MA, et al. National Healthcare Safety Network (NHSN) report, data summary for 2006, issue June 2007. Am J Infect Contr 2009; 35:290-301.

11. Isaccs D. A ten year, multicentre study of coagulase negative staphylococcal infections in Australasian neonatal units. Arch Dis Child Fetal Neonatal 2003; 88:89-93.

12. Klein MD, Rood K, Gramham P. Central venous catheter sepsis in surgical newborns. Pediatr Surg Intern 2003; 19:529-532.

13. Zaidi AKM, Huskins WC, Thaver D, Bhutta ZA, Abbas Z, Goldmann DA. Hospital-acquired neonatal infections in developing countries. Lancet 2005; 365:1175-1188.

14. Krediet TG, Mascini EM, Rooij E, Vlooswijk J, Paauw A, Gerards LJ, et al. Molecular epidemiology of coagulase-negative staphylococci causing sepsis in a neonatal intensive care unit over an 11 year period. J Clin Microbiol 2004; 42:992-995

15. Stoll BJ, Hansen N, Fanaroff AA, Wright LL, Carlo WA, Ehrenkranz RA, et al. Late-onset sepsis in very low birth weight neonates: the experience of the NICHD Neonatal Research Netwok. Pediatrics 2002; 110:285-891.

16. Celebi S, Hacimustafaoglu M, Ozdemir O, Ozakin C. Nosocomial Gram-positive bacterial infections in children: results of a 7 year study. Pediatr Int 2007; 49:875-882

17. Ben Jaballah N, Bouziri A, Mnif Khaled, Hamdi A, Khladi A, Kchaou W. Epidemiology of hospital-acquired bloodstream infections in a Tunisian pediatric intensive care unit: a 2-year prospective study. Am J Infect Control 2007; 35:613-618. 